\title{
Coyote in Geiogamah's Coon Cons Coyote and Two-Rivers' Coyote Sits in Judgment
}

https://doi.org/10.33806/ijaes2000.21.1.9

\author{
Raad Kareem Abd-Aun \\ University of Babylon, Iraq
}

\begin{abstract}
The trickster is a character that inhabits the myth, folklore, and oral literature of many cultures and civilizations, and it takes many shapes. The coyote is one of the trickster figures in Native American cultures. It is found in oral Native American literatures, and then found its way into Native American literature by modern Native American writers. This paper attempts to shed light on the trickster, Coyote, in Native American drama, an area, in the researcher's opinion, which received much less attention in comparison to poetry and novel. The paper focuses on two plays, Hanay Geiogamah's Coon Cons Coyote and E. Donald Two-Rivers' Coyote Sits in Judgment.
\end{abstract}

Keywords: coyote; Native American drama; Geiogamah; Two-Rivers

\section{Introduction}

Paul Radin argues that the trickster is a "creator and a destroyer, a giver and a negator, he who dupes others and who is always duped himself. He wills nothing consciously. At all times he is constrained to behave as he does from impulses over which he has no control. He knows neither good nor evil yet he is responsible for both. He possesses no values, moral or social; he is at the mercy of his passions and appetites, yet through his actions, all values come into being." Nevertheless, not only has he, so our myth tells us, possessed these traits (Radin, 1956: ix).

Tricksters are archetypal characters appearing in the myths of many different cultures playing different roles. A trickster possesses a great degree of intellect and uses it to play tricks. Being paradoxical in nature, not only does this creature embrace all aspects and characteristics of contradiction and ambiguity, he is a crafty creature who uses cunning to get food, steal precious possessions or simply cause mischief (Nadelberg, 2008: 6-9).

Although his name and characteristics change dramatically from one culture to another, his appearance in different cultural stories is very much the same. Hermes illustrates the role of trickster in Greek mythology through his patronage of thieves and being credited for the invention of lying, a gift he passed on to Autolycus, who in turn passed it on to Odysseus. In the North Germanic mythology, the trickster exhibits a gender and form variability - the mischief-maker is Loki becomes pregnant. He turned into an adult female who later gives birth to Odin's eight-legged horse Sleipnir. In African myth, particularly those involving the spider Anansi, the trickster often appears as a mythological figure and a rival of the sky god whereas a wide range of myths across Africa represent the trickster as a human 
(e.g., the stories of Yo in Benin). Examples of Asian trickster figures are the Chinese folk hero Wen-chang, and the Thai folk hero Sug (Carroll, 1984: 106-119).

In Native American mythology, the trickster plays an important role as the most ubiquitous character. Shifting shapes between animal and human within the course of the story, he appears in the northwest societies as Raven, Mink, or Blue Jay, while as a Spider in many southwest tales. To many northeast Indians, he is Wisakedjak, Anglicized to Whiskey Jack, the trickster-hero. In western coyote tales of the Native Americans, he is the "selfish-buffoon" - "selfish" because so much of his activity is oriented toward the gratification of his enormous appetites for food and sex, and "buffoon" because his action backfire at him at the end leaving him looking incredibly foolish (Carroll, 1984: 106-119).

In his many manifestations, "the trickster is a mischievous jokester, and is often depicted as prone to human temptations, greed, laziness, and lust. Traditionally, trickster stories function to show the pitfalls of human behaviour providing valuable lessons for individuals and groups to live in balance with each other and the natural world. Native American playwrights such as Hanay Geiogamah, Tompson Highway, Marie Clements and many others have used tricksters as comic, witty troublemakers who dramaturgically push the action forward. They provide insight and humour to stir up relationships or solve problems presented in the plays" (Mohler, n.d., 6). The trickster is also used by these playwrights to enforce their cultural identity which can be defined as "the feeling of belonging to a certain social or cultural group" (Yousef, 2019: 71).

\subsection{Hanay Geiogamah: a biographical sketch}

Hanay Geiogamah began his artistic journey as a young playwright, a movie producer, a Professor in the School of Theatre, Film, and Television at the University of California, Los Angeles, and director, who staged his first plays with his own all-Indian theatre group, 45. In high school, he initiated his first Indian club and was quite active as editor of the student newspaper. After graduating from high school in 1963, he attended the University of Oklahoma majoring in journalism continuing his work on the student newspaper over the course of six years. In the summer of 1970, Geiogamah served as an intern for Senator Edward Kennedy, going to work for the Bureau of Indian Affairs (BIA) under reformist director Louis Bruce (Vassar, 2002: 2, 107).

It was in the fall of 1972 that he wrote and produced Body Indian with the American Indian Theatre Ensemble (AITE) at New York's La Mama Theatre. In May of 1973, he moved to New York in a thrill to commit his full time to theatre, which made him stops working for the BIA in Washington. From 1973 to 1975, he directed what later became the Native American Theatre Ensemble (NATE) in three productions, one of which premiered in Berlin (McClinton-Temple and Velie, 2007: 133-135).

In 1976, NATE was disbanded and Geiogamah worked as a free-lance director, playwright, and lecturer on American Indian arts and communications at a variety of locations across the United States. In 1980, Geiogamah moved back to New York, where, as Artistic Director, he founded Native Americans in the Arts 
(NAIA), an updated and extended NATE that disbanded in 1982. He moved to Los Angeles and UCLA fulltime in 1984. There he founded and directed the American Indian Registry for Performing Arts (AIRPA) until 1988 (McClinton-Temple and Velie, 2007: 133-135).

In the late 1980s, Geiogamah also worked with dance director Barbra Schwei to create American Indian Dance Theatre (AIDT), a dance performance group that went on successful worldwide tours from 1988 to 1989, closing with a "Great Performances" special on the Public Broadcasting System. In the nineties, Geiogamah worked more with film than theatre, including several projects for Turner Network Television as well as some independent films. Academic works concentrating on Geiogamah have been few and far between. His first three published plays have been mentioned and studied in a few critical essays and discussions of Native American theatre and humour. Monographs, articles, book and play reviews focused on them discuss Geiogamah's published works in detail, while giving little recognition to his other plays - "Coon Cons Coyote" (1973), "War Dancer" (1977), "Body Indian Part II" (1981), "War Dancers" (1981-2), "Land Sale" (1984), and the complementary one-act "Grandma and Grandpa" (1985) (Vassar, 2002, pp. 300-313).

\subsection{Coon Cons Coyote's place in Native American theatre}

According to Shari Huhndorf, through the end of the nineteenth century, American play writers and drama-lovers had an almost obsessive interest into the Indians wars. They rewrote countless dramatic texts concerning their events in ways that concealed the violence of defeat and affirmed European colonial dominance. "Plays like Metamora euphemistically made the Indians "disappearance" seem predictable but tragic by romanticizing their Native characters, a manifestation perhaps of superficial regret combined with a need to eliminate Indians even more unreal." (Huhndorf, 2006: 289) Others on the other hand, portrayed Natives as savages who deserved their punishing destiny like James McCloskey's Across the Continent (1870) and Ned Buntline's the Scouts of the Prairie; or, Red Deviltry as It Is (1872), one of the many plays, Huhndorf continues, built on the exploits of Buffalo Bill. (Huhndorf, 2006: 289) Both kinds of plays supported on-going processes of denial and genocide. However, it was not only the content of these narratives that proved significant but also rather who wrote the plays, who acted in them, and for what audiences - these aspects of the theatre reflected and participated in the larger dynamics of Indian-white relations. It was until the middle of the twentieth century, "writers and actors of 'Indian plays' were almost exclusively white". Native Americans were almost deprived of the social power and material resources to represent themselves in the broader culture, as were the enormous majority of audience members; it required a degree of privilege, influence, and education that few Indians possessed to fulfil these roles (Huhndorf, 2006: 289-90).

Geiogamah's importance in the history of Native American theatre cannot be overestimated. His choice of character likewise. It is substantial for Geiogamah that Coyote is particularly a Kiowa trickster. For Geiogamah, the stage becomes a venue for continuing and adapting cultural traditions, a project that is also important in his 
play, Coon Cons Coyote. He recalls how someone from another tribe or a Kiowa might say informally, "You know, coyote's in me, or something" (Lincoln, 71). However, Coyote is present as a trickster in many other Native American cultures, and by choosing the more prominent trickster figure Coyote over the specifically Kiowa trickster Saynday, Geiogamah is attempting to establish a native theatre that is "not restricted to one tribe" (Pinazzi, 2000: 187 in Katanski, 2005: 195). It gives Geiogamah's plays their importance in native American history. He hoped it would show the harsh roles natives had to live by as he stated in his grant proposal:

For decades Indians have been portrayed in films and television in a manner entirely derogatory to their cultural and mental well-being. Who on this earth can enjoy seeing themselves and their race portrayed as fiendish savages and murderers who can scream blood-curdling yelps as seemingly their only form of vocal communication? It is thought by many American Indian leaders and activists that this unabated, corrupt use of American Indians by the American dream makers has been a major factor in the deepening cultural and spiritual malaise of American Indians (Geiogamah, 1999: 160 in Huhndorf, 2006: 290).

Geigomah comments on his twin passion to reportage and politics which found away in his dramatic work saying: "by 1968," he reminisces," my political crusading and my interest in theater began to merge, initially in a conception of writing plays which would depict the truth about the conditions of American Indians" (Pinazzi, 2000: 177 in Huhndorf, 2006: 300).

In his work, Geiogamah tends to mock and attempts to undermine stereotypes, while at other times he questions the Indian lives complexities shaped by centuries of colonialism. Although he is interested in these effects left by their history, he usually avoids simple hostilities between the dominant society and Native cultures, including the ways some Indians have become implicated in their own cruelty, he illustrates instead their complicated interrelationships. Indeed, the question of responsibility and accountability is one of the most complex and controversial aspects of his work, and his plays aim to enable Native communities to "look at our situation in politics and the social environment" and, ultimately, to change it (Geigomah, 2000: 173 in Huhndorf, 2004: 298). In brief, Geiogamah portrayed a theater in which politics and representation are intimately connected, and drama serves as a means for social intervention (Huhndorf, 2004: 299).

\subsection{The play and the myth}

Coon Cons Coyote is an improvisation on the Nez Perce tribal poem that states: "Coon Cons Coyote, Coyote Eats Coon, Meets Up With Farting Girl, Gets Immured in a Stone House, Eats His Eyes, Eats His Balls, Gets Out, Gets Bird boy's Eyes, Loses Them, and Gets Them Back Again" (Rothenberg, 1972: 102, 105). Geiogamah declared that NATE based the tale on Jerome Rothenberg's 1972 anthology Shaking the Pumpkin: Traditional Poetry of the Indian Americans. Although, the poem's title does not quite appear in the Rothenberg anthology. Instead, two similar poems appear: "Coon cons Coyote, Coyote eats Coon, Coyote fights Shit-Men, gets immured in a rock-house, eats his eyes, eats his balls, gets 
out, con Bird-Boy for eyes, loses them, to the birds \& gets them back," and "Coyote borrows Farting Boy's asshole, tosses up his eyes, retrieves them, rapes old women $\&$ tricks a young girl seeking power" (Rothenberg, 1972: 105). Even though each poem has different length - the first only 63 lines, the latter eleven pages, they contain partially the same description, such as the granddaughters carrying a disguised Coyote to a feast while he tries to have sex with them. The second adds dialogue. The play's adaptation of both poems is then "selective on the basis of theatrical practicality. It creates a comprehensive story, by combining subtracts, and shortens material from both poems to create an inclusive story" (Vassar, 2002: 165).

The play begins as Coon cons Coyote into thinking he can find food. Although Coyote is unsuccessful in all three attempts and ends up empty-handed, eventually he tricks and eats Coon in retaliation. Coyote then meets up with Farting Girl, who tricks him into taking her farting arrows until he figures out how to stop farting by dropping the arrows. As protection from these "foes," Coyote wishes for a rock house, but once it is built, he forgets that he might get hungry. Without anything to eat, he is forced to eat his eyes. He is helped out of the house by another animal helper, Sap sucker, and her bird friends. Sap sucker retells what she did to him to prevent him eating, so instead he gives them coloured scarfs for their help. Coyote next messes with the arrogant Bird Boy, a half-bird, half boy creature, whom Coyote tricks into snipe hunting and exchanging him his flower eyes for Coyote's sunflower eyes, which wilt when the sun goes down. Coyote promptly loses them to hummingbirds, who identify the eyes as Bird Boy's and give them back. Coyote then encounters One-Eyed Old Woman and her Three Granddaughters. He hits the Old Woman in the head and drags her off, putting on her shawl to disguise himself, which he uses to beg each of the granddaughters to carry him over their backs. One by one they do so, Coyote almost losing his disguise in the process as he tries to copulate with each one until the Third Granddaughter screams out, "Grandma, what are you trying to stick in me?" (Geiogamah, 1999: 146). The play then closes as it opened, with members of the company tossing Coyote's eyes around while he tries to retrieve them (Geiogamah, 1999: 127-146).

Traditional trickster plays carry the same message whether Coyote or any other animal god-helper from Native American lore like Rabbit, Raven, Bluejay, Spider, or Mink. The play is at first a comedy, then on a secondary level a moralistic one in thought, choice, and action that is given a live performance. In Coon Cons Coyote, we are to see human qualities, mistake, weakness, vulnerability. In this sense, Coyote "ridicules our ordinary behaviours by breaking their hold on us" (Rothenberg, 1972: 423). The figure of Coyote takes us to witness both levels whether it is humour or a lesson to be taught, the lesson is not to emulate Coyote's actions, for Coyote is what he is in any traditional Indian tale: a selfish fool who does not think before he acts. He is too much of an arrogant to look at his action an ironic to his attachment toward his eyes. Instead, as Bruckner observed, the play works "[...] in the manner of Indian tales, if any of them [...] stoops to enjoy the triumph, he too is done in by fate, or by the coyote" (1985:3). The play is the best example for the theme of justice. It is initiated in the scene between Coyote and Coon that creates the play's title ending up with Coyote eating Coon as a revenge 
for the tricks the latter played on the former. Coon first fools Coyote into thinking he can turn a pillow of skunk cabbages into fish overnight, that he can catch fish from an anthill with his penis, and that he can beg humans in the audience for food. In all three attempts, Coyote ends up empty-handed, bitten, and unsuccessful. With the knowledge that Coon has tricked him a third time, Coyote sets up his revenge. He tricks Coon into bringing him food_crabs-from the river and tells Coon to watch out for black beings in the river. Disguised as a black being, Coyote wounds Coon with a rifle then tricks Coon to let him look at the wound "in the fat part" of his body - an invitation Coyote uses to eat Coon. Coon was a trickster to the fool that Coyote is, but he received punishment for it, as will Coyote. Justice is circular, and it always finds its way back (Vassar, 2002: 166-167).

Perhaps one of the more essential ways the play enforces its Native American heritage message is through its display of etiological myths, myths that describe the origins of the world. Coyote is a god like creature even though he acts as a trickster fool. For instance, one Hopi myth recalls him sitting on a cloud cutting his fingernails without caution. As the cut nails fly from his fingers, they float down to earth and change into human beings. In Coon Cons Coyote, Coyote is aware of his creativity. Once his bird friends help him out of the rock house, they remind him of his promise not to eat them (though he tries) and to give them a gift or he will not be warned of danger anymore. Coyote then keeps his promise, handing out coloured scarves to each bird: blue for Blue Jay, red for Red Headed Woodpecker, and yellow for Yellow Bellied Sapsucker, who loses his scarf in a struggle with the greedy Crow. Coyote then tells Crow that "since you were so greedy, I will take away your song, (COYOTE tears at Crow's throat), and you shall wear black" (Geiogamah, 1999: 141).

The musical background of the play added a whole new level on the acting of the play as Geiogamah stated in his interview: "We used song, dance and storytelling tradition to tell a tribal myth of creation [Na Haaz Zan]. We gave wild comic life to Coyote [...] We were only scratching the surface, and the larger possibilities were visible, real, not pipe dreams" (Geiogamah, "Self-Interview" in Krupat and Swann, 2000: 148-9).

A play like Coon Cons Coyote becomes a declaration from Geiogamah that Indians have arrived to tell the story of their present and past. By repeating their past cultural traditions, Geiogamah is trying to throw off the restraints of performing simply modern realistic drama and adapt traditional oral material from their native past into stageable theatre. Such a piece can teach in much the same way as the traditional tales of the past did, only to a broader audience. He derived public attention to Native issues and generated financial support for cultural, educational, and political projects as it were, for the demands for social change that became more insistent in the 1960s. Commitments to sovereignty and other forms of antiracism and anticolonialism provided a common cause, especially for the younger generation. As Hanay Geiogamah described the mission of AITE, "we believe [it] can function as a component of the overall movement to achieve true equality and self-determination" (Geiogomah in Brown, 1973: 5). 


\subsection{E. Donald Two-Rivers' Coyote Sits in Judgment}

Every part of this earth is sacred to my people. We are part of the earth and the earth it is part of us. Whatever befalls the earth befalls the sons of the earth. If men spit upon the ground, they spit upon themselves, this we know, the earth does not belong to man, man belong to the earth (Haugo, 2005: 6).

Literature tells truth about the past that history cannot articulate. This is altruism with a particular resonance in the Native American context because until the watershed year of the late 1960's and early 1970's, Native Americans were either ignored or grossly misrepresented by conventional histories (Porter, 2005: 39).

The Native Americans have long had an immediate relationship with their physical environment. As a result, the environment emerged as a topic of widespread public interest in the tumultuous 1960 and 1970, not only were people paying more attention to the relationship between humans and the natural world, but the environmental dangers caused by industrial civilization were also becoming ever more apparent (Haugo, 2005:14).

Connecting the environment with societies and cultures through literature creates a new awareness of environmental issues. The current environmental crisis is a product of modern human culture. The thought of using land as a commodity and disregard environmental ethics worsened the ecological crisis. For Native Americans, land is considered not merely a stage on which the act is played but also as an active participant in the drama with major role played in the lives of the characters (Tariq and Bahramand, 2019: 226). It is a goddess and a mother, a giver of life, a nourisher, that needs to be cared for in the same way it cares for others.

Trickster tales are told around the world since ancient times. Trickster can be easy to recognize, but hard to reconcile. It is one slippery archetype that is said to be at the very foundation of civilization and culture. Trickster is teaching us through trickery since the beginning. It is an archetype we need to get familiar with if we want to attain a semblance of balance in the currently duplicitous cultural and political climate in which we find ourselves (Azaria, 2015: 5). Through his trickery, and sometimes even through his (un)intentional negligence of what is vital, the trickster teaches us about ourselves.

E. Donald Two-Rivers (July 29, 1945) was an Anishinaabe (Ojibwa) poet, playwright and spoken-word performer. He was born and raised in Emo township, Ontario, Canada. He came to Chicago at 16. He was an activist for Native rights since the 1970s. He is also an accomplished poet. A critic of "victim politics", TwoRivers is a strong supporter of programs that give disadvantaged Native peoples the chance to stand on their own two feet (Penny's Poetry Pages).

He had been critical of Euro-American directors and actors in the past, saying that "I believe that for non-Natives to perform a Native American play, they would 
first have to undergo a certain level of sensitivity training. In fact, I would require it for any of my plays." (Wikipedia)

E. Donald Two-Rivers was the founding (Artistic Director) of the Chicagobased Red Path Theater Company. In 2007, he returned to Chicago, to work on his last book In the Spirit of the Coyote. He died December 27, 2008 (Penny's Poetry Pages).

Two-Rivers' collection contains six plays many of which were produced by Chicago's Red Path Theatre Company, where Two-Rivers served as artistic director for several years. Some of Two-River's "usually comic, witty plays are decidedly urban in flavour" (Haugo, 2005: 196). He presents an intricate and multifaceted view of contemporary American Indian urban life; his plays range from one-act vignettes accessible to young adults to extended portrayals of the seedier side of urban existence. He also wants to make a public knowledge of "ecological dangers" through the use of ecocriticism which pleads for a better understanding of nature both interprets and represents the natural world (Devall 1985: 122).

\subsection{Coyote Sits in Judgement and the environment}

The one-act play Coyote Sits in Judgment opens with a character description that is nothing if not urban: "A grumpy coyote addicted to Starbucks's coffee and Whitman poetry. Also like to surf the Internet. Sometimes visit the porno pages, but doesn't know why - there are so many of them - irrelevant to this tale" (TwoRivers, 2001: 146).

In spite of the tribal diversity of the trickster, the playwright chooses the more prominent trickster figure (coyote) to teach the Native Americans the land ethics. The purpose of coyote is representing the dualities of life as a bringer of humour and order. By listening to coyote stories, we learn of the history and culture of Native Americans as well as the origins of the universe (Dawes, 2013: 84).

It is often questioned why Two-Rivers chose the coyote when it comes to using an animal as the main character of trickster tales. One suggestion relates to the biological nature of the real coyote and how it interacts with its environment. The second is that the coyote exemplifies all the traits that the trickster embodies. It is gluttonous, incredibly sexual and deceitful; it is also very creative, sometimes for the good of others, but mostly in his own favour (Dawes, 2013: 12).

Coyote must decide a court conflict between characters, Technology and Business, each suing the other for environmental destruction through the play. Each tries to prove that he is right and each one pretends that he demands a ruling for benefit of nature and society. Through the play, coyote is an adviser and guide to both Technology and Business. He discusses the problem, which is the issue of the environment and its destruction. He explains to them that the only one who is responsible for this destruction is the human because of his ignorance to nature and its resources and because of the misuse of technology: "The greenhouse effect is the result of humans changing things" (Two-Rivers, 2001:152).

"Coyote irreverently distracts himself from serious commentary on the environment to appease his stomach": (Haugo, 2005: 187). "Mankind is violently 
extracting nature resource faster than can be replaced - life can't be any sustained without limits and moderation. (Pause.) Dose anybody have some pizza?" (TwoRivers, 2001: 151). Perhaps this is meant to remind us that it is our pursuit of material gain that has distracted us from what is vital to our survival - nature and its preservation - in the same way Coyote's stomach distracts him from the issue he requested to judge.

Environmental issues have largely changed the idea about literature and the environment. In the twentieth and twenty-first centuries, literature has a profound effect on how to think about the relationship between human societies and how they affect the natural world is changed, (Willow, 2010: 137) or as Coyote puts it: "Mankind did not follow Nature's rules, they misused their spiritual powers for selfish purpose" (Two-Rivers, 2001: 150).

There is a relationship between human societies and everything bad happening to the natural world: mankind ignores natural law to his own benefit and turns a blind eye to any destruction happening to the environment: "The Creator made the world/ in perfect balance, but humans turned away/ from moral and spiritual principles./ [...] History. How many times has this very argument come up? Must mankind continually repeat old sin?" (Two-Rivers, 2001: 150, 153). Perhaps one of the more radical ways the play enforces its Native American heritage message is through its display of etiological myth, as exemplified by the extract (Vassar, 2002: 12). Coyote, while being a trickster fool, explains the dangers inherent in the reality of the world (Vassar, 2002: 14). The play is an examination of universal social problem and it remains a daring exploration of the seedier side of life, which is the ignorance of the environment and the mass destruction, which is caused by man, or as Coyote puts it, man "extracts more than he needs" (TwoRivers, 2001: 149).

\subsection{Coyote Sits in Judgement and the problems of today}

Human, or anthropogenic, negative impact on the environment includes changes to the biophysical environment and ecosystems biodiversity, and natural resources caused directly or indirectly by humans. These include global warming, environmental degradation, mass extinction and biodiversity loss, ecological crisis, and ecological collapse, modifying the environment to fit the needs of society is causing service effects, which became worse as the problem of human overpopulation continues. Some human activities that caused damage to the environment on a global scale include human reproduction, overconsumption, overexploitation, pollution, and deforestation (Trenberth, 2018: 10). The reduction in pollution and the gradual restoration of the ozone layer as the world opted to stay home to reduce the chances of infection with the COVID-19 is an evidence that human's everyday activities have dire consequences of the whole planet.

Man's positive effect on Nature can be realized through recycling, creating green open space laws, establishing wildlife reservations and parks, and reforestation (Brenner, 2018: 5) which is no more than the practical application of the fact that "mother earth isn't a resource, she is heirloom" (Ipina). Native Americans understood that what affects even the lowest creature in life, affects 
every one, which is why they choose to live in harmony with nature instead of against it. They never stayed in an area long enough to deplete the land and moved with the season in order not to use up all the resources in one location. "We are the land" is the fundamental idea embodied in Native American life. "The land is not really a place separate from ourselves, it's not means of survival, setting for our affairs [...], it's rather a part of our being, it's ourselves" (Allen, 1979: 5). Now, every human newly born is an environmental burden because humans are subtracting resources needed by other species (Brenner, 2018: 9).

Through the play, the trickster gives both technology and business (humanity in general) the solution for environmental restoration: "Reducing the destruction of the tropical rain forests would help to alleviate the greenhouse effect. [...] There must be balance, and me think that this can be only be achieved through equalizing the natural world with the supernatural world, life must be restored" (Tow-Rivers, 2001: 154, 151).

Coyote displays the problems and the solutions, desiring both Technology and Business to work together in harmony to protect nature. However, at the end, and because of his deceitful nature, we find that he exploits nature to his own ends. Therefore, he ends the play causing more damage "He signed Asinine Option Nine, a major attack on American forests, and then he disappeared" (Two-Rivers, 2001: 155).

In the play, Two-Rivers uses a more secular approach to trickster (Coyote) in order to create a connection between cultures. He states the idea of the trickster crossing cultures by arguing that the trickster is the new metaphor between communal tribal cultures and the cultures that oppose traditional connections. $\mathrm{He}$ emphasizes that trickster figures have their roots in the past but exist very much in the present (McClinton-Temple, 2007: 83).

It is not hard to imagine that we currently live in a trickster world where the opposites do divide into extremes in cultures such as the unfortunate global reality of severe poverty and extreme wealth. Polarized political views on critical topics like abortion, guns, fossil fuels, the environment, and so forth, affect us in profound ways now and will continue to for generations to come. We are reaching a tipping point and mercurial tricksters are still on the scene, attempting to show culture its shadow and wake us up to the inevitable changes that are afoot. In mythological terms, the battle between the forces of creation and destruction, as typified by trickster polarity are as alive and well in the modern world as they were for our ancestors. Trickster makes its way to the world stage via the psyche of the individual. It is the duality which resides within the individual that rises up and moves from the interior realms of psyche to the outer, collective sphere. It is believed that we must come to terms with inner conflicts in order to gain more clarity about the outer conflicts we seem, as a culture, to be mired in (Azaria, 2009: $31)$.

\section{Conclusion}

Geiogamah's Coon Cons Coyote is one of the first plays to introduce the trickster on the stage. The play cannot be considered a simple dramatization of a myth or a 
folk tale. It is a breakthrough for a culture that was not given its fair chance at representation, not only on the stage, but also in media in general.

Placing the trickster on the stage is a powerful statement that this culture is more than worthy of occupying a place on the world stage. Its message implies that it is a versatile, genuine, and rich culture that can thrive and prosper once it is given the chance, as writers like Geiogamah and other have shown.

Coyote Sits in Judgment has no time constraints to its story - it means that it could be long ago, now, or maybe in the future (Two-Rivers, 2001: 147). It deals with a problem that is universal and for all people, the environmental crisis. It highlights a new way of treating the natural world putting responsibility on man to see how cultures are affecting the environment.

Two-Rivers discusses the problem and the solution of environmental issues in the play using the most ubiquitous character in Native orature that crosses cultures, the Trickster. Other characters that represent the material needs of man which destroy nature, like Technology and Business, are used.

Today, the coronavirus crisis has changed the way we see the world. It reminds us of the fragility of life (Hamwey, 2020: 3). With entire populations ordered to stay home, air quality improved largely because of the reduction in factories and road traffic emissions of carbon dioxide and related ozone. This crisis shows us how human activities affect the environment and contribute to pollution (Hamwey, 2020: 11).

In this regard, an ecological vision, which has close link with the public life, must be promoted. Nature is an integral part of human culture and civilization, with the death of nature, culture and civilization will come to an end: (Kucharska, 2002: 6) "Remember what you do to mother earth, you do into your selves" (Two-Rivers, 2001: 155).

The trickster Coyote took a long leap, a one of faith albeit, from Geiogamah's to Two-Rivers' depictions. Geiogamah's is a foundational representation, a shy, first attempt at introducing a subject related to a culture that has been largely neglected by mainstream media and culture. Two-Rivers' depiction shows a much more universal concern with issues that are no related to one specific culture, but to the whole human race. Such a move from the specific to the universal must have gone through many transitional stages that deserve attention. Perhaps it is time for a full-scale study of trickster(s) in Native American drama.

Raad Kareem Abd-Aun

University of Babylon, Iraq

ORCID Number: 0000-0001-9224-742X

Email: abdaun.raad@gmail.com 
References

Allen, Paula Gunn. (1979). "The Sacred Hoop: A Contemporary Indian Perspective on American Literature". In Geary Hobson (ed.), The Remembered Earth: An Anthology of Contemporary Native American Literature, 222-239. Albuquerque: The University of New Mexico Press.

Azaria, Tina. (2015). "Trickster Archetype of Changing Times". Depth Insights, 8: 29-33. https://www.depthinsights.com/Depth-Insights-scholarlyezine/ezine-issue-8-winter-2015/ (Retrieved on December 17, 2019).

Brenner, Laurie. (2018). "Positive Effects of Humans on the Ecosystem". https://sciencing.com/positive-effects-humans-ecosystem-5869462.html (Retrieved on February 12, 2020).

Brown, Kent R. (1973). "Opening on the Education Scene: A Native American Theatre Ensemble". Journal of American Indian Education, 13 (1): 1-6

Bruckner, D. J. R. (1985). "The Stage: 'Red Bwai' and 'Coyote.” Rev. of Coon Cons Coyote. The New York Times, 4 August 1985: (C3). https://www.nytimes.com/1985/08/04/theater/the-stage-red-bwai-andcoyote.html (Retrieved on May 9, 2020).

Carroll, Michael P. (1984). "The Trickster as Selfish-Buffoon and Culture Hero". Ethos, 12 (2): 105-131.

Dawes, Brigit. (2013). Performing Memory, Transforming Time: History and Indigenous North American Drama. Albany: University of New York Press.

Devall, Bill. (1985). Deep Ecology: Living as If Nature Mattered. Salt Lake City: Peregrine Smith Books.

Geiogamah, Hanay. (1999). "Coon Cons Coyote”. In Hanay Geiogamah and Jaye T. Darby (eds.), Stories of Our Way: An Anthology of American Indian Plays, 127-154. CA: UCLA American Indian Studies Center.

Geiogamah, Hanay. (2000). "The New American Indian Theater: An Introduction." In Hanay Geiogamah and Jaye T Darby (eds.), American Indian Theater in Performance: A Reader, 159-64. Los Angeles: University of California Press. In Shari Huhndorf. (2006). "American Indian Drama and the Politics of Performance". In Eric Cheyfitz (ed.), The Columbia Guide to American Indian Literatures of the United States since 1945, 288-318. NY: Colombia University Press.

Geiogamah, Hanay. (2000). "Self-Interview." In Arnold Krupat and Brian Swann (eds.), Here First: Autobiographical Essays by Native American Writers, 143-64. New York: The Modern Library.

Hamwey, Robert. (2020). "Environmental Impacts of Coronavirus Crisis, Challenges Ahead". https://unctad.org/news/environmental-impactscoronavirus-crisis-challenges-ahead (Retrieved on May 9, 2020). 
Haugo, Ann. (2005). “American Indian Theatre”. In Joy Porter and Kenneth M. Roemer (eds.), The Cambridge Companion to Native American Literature, 189-204. Cambridge: Cambridge University Press.

Huhndorf, Shari. (2006). "American Indian Drama and the Politics of Performance". In Eric Cheyfitz (ed.), The Columbia Guide to American Indian Literatures of the United States since 1945, 288-318. NY: Colombia University Press.

Ipina, David. "13 Quotes That Remind Us to Protect Mother Earth". https://indiancountrytoday.com/archive/13-quotes-that-remind-us-toprotect-mother-earth-40y-MhzbbUeLOO5HY6yHew (Retrieved on June 29, 2020).

Kucharska, Veronika. (2002). "Native Americans and Ecology". Unpublished MA Thesis. Masaryk University, Brno, Czechia.

Lincoln, Kenneth. (1989-1990). "Indians Playing Indians". MELUS, 16 (3): 9198.

Mohler, Courtney Elkin. "American Indian Theatre and Performance". https://webpages.scu.edu/ftp/cmohler/Greenwood_Mohler_Indian_Theatr e.pdf (Retrieved on 17 January, 2021).

Nadelberg, Laura R. (2008). "Cultural Heroes and Mirrors of Darker Desires: Transitioning Tricksters of our Past into Contemporary Society". Unpublished Thesis. Connecticut College, New London, Connecticut, USA.

Penny's Poetry Pages. "E. Donald Two-Rivers". https://pennyspoetry.fandom.com/wiki/E. Donald Two-Rivers (Retrieved on January 17, 2021).

Pinazzi, Annamaria. (2000) "The Theater of Hanay Geiogamah." In Hanay Geiogamah and Jaye T. Darby (eds.), American Indian Theater in Performance: A Reader, 175-194. Los Angeles: UCLA American Indian Studies Center.

Porter, Joy. (2005). "Historical and cultural contexts to Native American literature". In Joy Porter and Kenneth M. Roemer (eds.), The Cambridge Companion to Native American Literature, 39-68. Cambridge: Cambridge University Press.

Radin, Paul. (1956). The Trickster: A Study in American Indian Mythology. NY: The Philosophical Library.

Rothenberg, Jerome. (1972). Shaking the Pumpkin Traditiona Poetry of the Indian North Americas. NY: Doubleday \& Company, Inc.

Tariq, Sana, and Bahrmand Shah. (2019). "Environment and Literary Landscape: An Ecological Criticism of Louise Erdrich's Novel Tracks". Global Social Sciences Review, IV (I): 226-234. DOI: 10.31703/gssr.2019(IV-I).21.

Tow-Rivers, E. Donald. (2001). Briefcase Warriors: Stories for the Stage. Norman: University of Oklahoma Press.

Trenberth, Kevin E. (2018). "Climate change caused by human activities is happening and it already has major consequences". Journal of Energy \& 
Natural Resources Law, 36 (4): 463-481. DOI: 10.1080/02646811.2018.1450895.

Vassar, Andrew Paul. (2002). "Hanay Geiogamah, Kiowa-Delaware Playwright: A Critical Biography”. Unpublished Dissertation. University of Arkansas, Fayetteville, Arkansas, USA.

Vassar, Andrew. (2007). "Geiogamah, Hanay". In Jennifer McClinton-Temple and Alan Velie (eds.), Encyclopedia of American Indian Literature, 133135. NY: An Infobase Publishing.

Wikipedia.

"E.

Donald

Two-Rivers".

https://en.wikipedia.org/wiki/E._Donald_Two-Rivers (Retrieved on January 17, 2021).

Willow, Anna. (2010). "Images of American Indians in Environmental Education: Anthropological Reflections on the Politics and History of Cultural Representation". American Indian Culture and Research Journal, 34 (1): 67-88. ERIC Number: EJ912987.

Yousef, Tawfiq. (2019). "Cultural Identity in Monica Ali's Brick Lane: A Bhabhian Perspective". International Journal of Arabic-English Studies (IJAES), 19 (1): 71-86. doi.org/10.33806/ijaes2000.19.1.4. 